\title{
Correlation of Maxillary Sinus to the Roots of Maxillary Posterior Teeth and a Review of Literature
}

\author{
Ch.Gowrisankar ${ }^{1}$, Thanmayi $P^{2}$, Suprabath $\mathbf{P}^{3}$, Hyandavi Balla ${ }^{4}$ \\ ${ }^{1}$ MDS (Dept of Oral and Maxillofacial Surgery) \\ ${ }^{2}$ BDS, GITAM Dental College and Hospital \\ ${ }^{3}$ BDS, GITAM Dental College and Hospital \\ ${ }^{4}$ Post Graduate Student (Dept. of Oral Pathology and Microbiology), Gitam Dental College and Hospital
}

\begin{abstract}
An anatomical description and relationship between the root apex of the maxillary tooth and the inferior wall of the maxillary sinus are essential for diagnosing sinus pathoses and planning a proper dental implantation. Therefore identifying the degree of proximity as well as the cortical thickness between the root apex and the inferior wall of the sinus is useful for surgical procedures.
\end{abstract}

Keywords: Maxillary sinus, Maxillary posterior teeth, Extraction complications, Orthodontics, Radiographic

\section{Introduction}

The maxillary sinus is the largest of all the paranasalsinuses; at 10 weeks in utero is the first to develop. After birth sinus continues to pneumatize into the developing alveolar ridge as the permanent teeth erupt. At 12-13 years the sinus floor is level with nasal floor and at age 20, with completion of eruption of the $3^{\text {rd }}$ molar, the pneumatization of the sinus ends. ${ }^{1}$

The adult sinus is variable in its extensions. Its floor extends between adjacent teeth or between individual in about half the population, creating elevations in the antral surface (commonly referred to as hillocks) or protrusions of the root apices into sinus. Histological sections show that the most of the roots that protrude radiographically into sinus are actually enveloped by a thin cortical layer with perforation in $14 \%$ to $28 \%$ of the cases. ${ }^{2}$

An anatomical description and relationship between the root apex of the maxillary tooth and the inferior wall of the maxillary sinus are essential for diagnosing sinus pathoses and planning a proper dental implantation. Therefore identifying the degree of proximity as well as the cortical thickness between the root apex and the inferior wall of the sinus is useful for surgical procedures. ${ }^{3}$

Tooth roots that protrude into the maxillary sinus can have various implications, including the following.

1) Implants. Wehrbein and diedrich described a positive correlation between the length of the root projection on the maxillary sinus in panoramic radiograph and the amount of pneumatization after extraction. Sinus expansion after extraction can greatly decrease the bone height available for the implant placement.

2) Extraction complication.Oroantral fistulae or root displacement into the sinus cavity are a frequent complications after extraction of the first and second molars.

3) Endo antral syndrome. In endoantral syndrome, the spread of pulpal disease beyond the confines of the dental supporting tissues into the maxillary sinus causing sinusitis may be present.

4) Orthodontics. Intrusion or bodily movement of the teeth across the sinus floor by orthodontic treatment have been shown to cause moderate apical root resorption and higher degree of tipping. ${ }^{2}$

\section{Aims and Objectives}

The aim of the study was to investigate the relationship of the posterior tooth to the maxillary antrum and to assess any correlation in comparison of the right side to the left side of the patient, and between the male and female patients.

\section{Materials and Methods}

In this study paranomic radiographs were selected from dental records of the patients who completed dental treatment at the department of oral and maxillofacial surgery, MeenakshiAmmal Dental College, Chennai. The ethical committee of MAHER University has approved the study design.

The study sample size includes a total of 150 subjects; both male and female are included in the study with an age ranging from $12-60 \mathrm{yrs}$.

A total of 150 paranomic radiographs were collected and the sinus lining and the root tips of the posterior tooth are traced on them. Perpendicular lines are drawn connecting the deepest point of the maxillary sinus floor to the root rips of the maxillary first and second premolars and molars, and the distances were measured and noted down. ${ }^{4}$ 


\section{International Journal of Science and Research (IJSR) \\ ISSN (Online): 2319-7064}

Index Copernicus Value (2015): 78.96 | Impact Factor (2015): 6.391

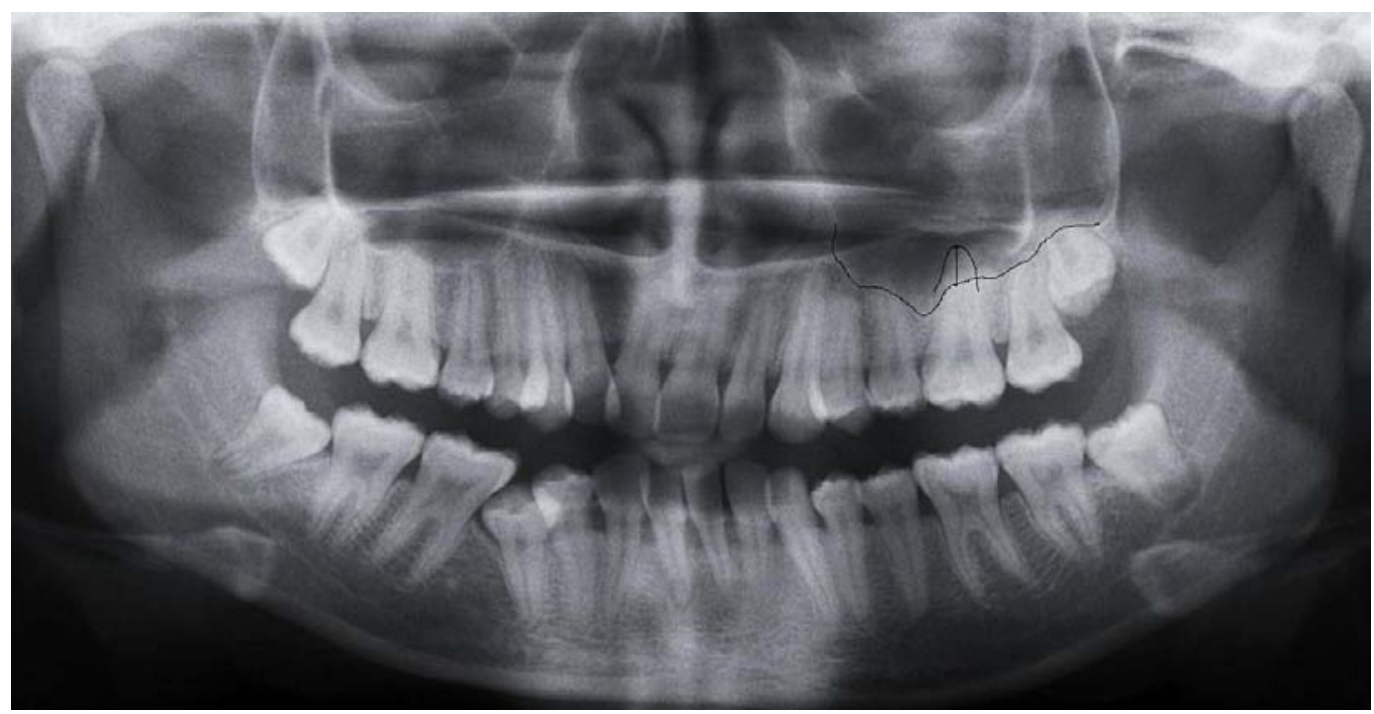

Diagrammatic representation of the method

The radiographic images were grouped according to the relationship between the root tips and the maxillary sinus lining as follows:

Group 1: root tips in contact with sinus floor

Group 2: root tips penetrating into the sinus floor

Group 3: root tips below the sinus floor.

Distances were measured for each tooth and individual roots on either side. Root tips in group 1 were numbered 0 , those in group 2 were given positive number and those in group 3 were given negative number. Mean, standard deviation and minimum and maximum valves were calculated for all right and left premolar and molars.

\section{Results}

The total number of patients included in the this study was 150 .

\section{Gender:}

In our study the male to female ratio was 1:1.2

\begin{tabular}{|c|c|c|}
\hline Patient & Percentage & Frequency \\
\hline Male & 42 & 63 \\
\hline Female & 58 & 87 \\
\hline
\end{tabular}

Age:

The mean age of the patients in the study was 22 years ranging from $12-60 \mathrm{yrs}$.

Mean, standard deviation and the minimum and maximum values in comparison of the right and left sides is given in the table below:

\section{Right side}

\begin{tabular}{|c|c|c|c|c|c|}
\hline Tooth & $N$ & Mean & $\begin{array}{c}\text { Standard } \\
\text { deviation }\end{array}$ & Minimum & Maximum \\
\hline $1^{\text {st }}$ premolar & 142 & -4.75 & 5.782 & -20 & +5 \\
\hline $2^{\text {nd }}$ premolar & 148 & -0.66 & 3.884 & -20 & +4 \\
\hline $1^{\text {st }}$ molar mesiobuccal & 149 & 1.66 & 2.514 & -10 & +7 \\
\hline $1^{\text {st }}$ molar distobuccal & 149 & 1.58 & 2.099 & -9 & +6 \\
\hline $1^{\text {st }}$ molar palatal & 149 & 1.73 & 2.410 & -8 & +6 \\
\hline $2^{\text {nd }}$ molar mesiobuccal & 150 & 1.86 & 2.00 & -6 & +7 \\
\hline $2^{\text {nd }}$ molar distobuccal & 150 & 2.13 & 2.112 & -5 & +7 \\
\hline $2^{\text {nd }}$ molar palatal & 150 & 1.83 & 2.123 & -4 & +7 \\
\hline $3^{\text {rd }}$ molar & 121 & 1.32 & 2.121 & -5 & +6 \\
\hline
\end{tabular}

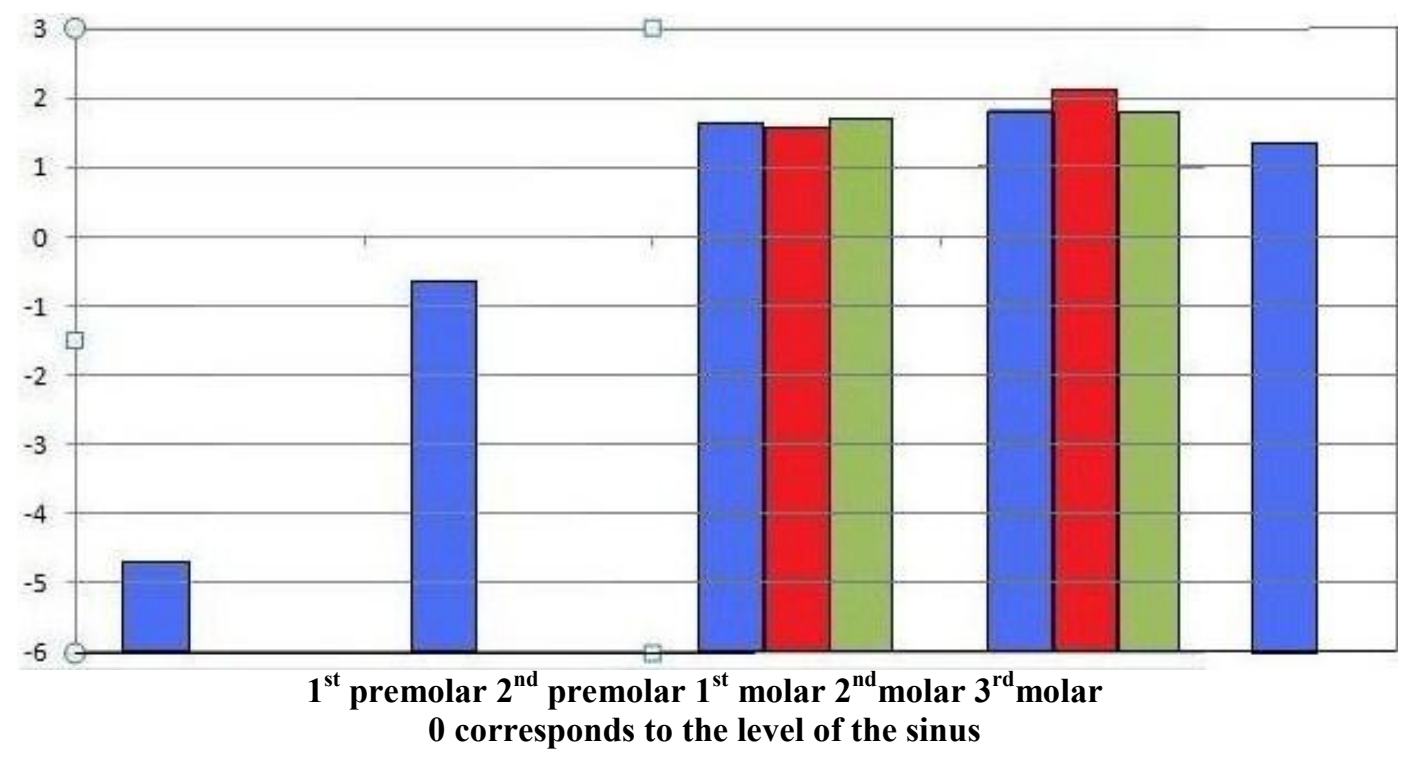

Volume 6 Issue 1, January 2017 www.ijsr.net 


\section{International Journal of Science and Research (IJSR) \\ ISSN (Online): 2319-7064}

Index Copernicus Value (2015): 78.96 | Impact Factor (2015): 6.391

Left side

\begin{tabular}{|c|c|c|c|c|c|}
\hline Tooth & $N$ & Mean & Standard deviation & Minimum & Maximum \\
\hline $1^{\text {st }}$ Premolar & 142 & -5.09 & 5.476 & -20 & +4 \\
\hline $2^{\text {nd }}$ Premolar & 149 & -0.45 & 3.991 & -18 & +6 \\
\hline $1^{\text {st }}$ molar mesiobuccal & 148 & 1.62 & 2.346 & -7 & +6 \\
\hline $1^{\text {st }}$ molar distobuccal & 148 & 1.72 & 2.195 & -6 & +7 \\
\hline $1^{\text {st }}$ molar palatal & 148 & 1.78 & 2.604 & -5 & +7 \\
\hline $2^{\text {nd }}$ molar mesiobuccal & 150 & 1.98 & 1.926 & -7 & +6 \\
\hline $2^{\text {nd }}$ molar distobuccal & 150 & 2.15 & 2.429 & -7 & +9 \\
\hline $2^{\text {nd }}$ molar palatal & 150 & 1.90 & 2.062 & -9 & +7 \\
\hline $3^{\text {rd }} m o l a r$ & 128 & 1.28 & 2.012 & -4 & +6 \\
\hline
\end{tabular}

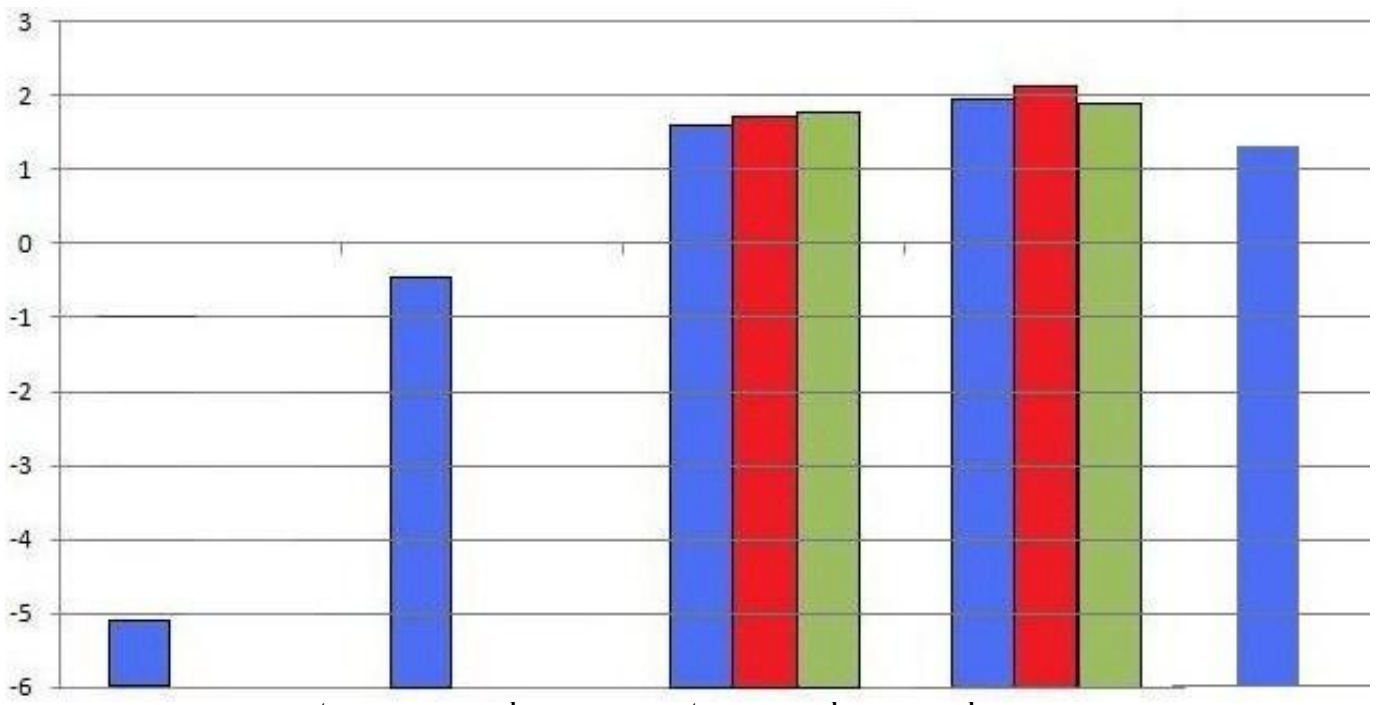

$1^{\text {st }}$ premolar $2^{\text {nd }}$ premolar $1^{\text {st }}$ molar $2^{\text {nd }}$ molar $3^{\text {rd }}$ molar 0 corresponds to the level of the sinus

Mean, standard deviation and the minimum and maximum values in comparison of the male to female Patients is given in the table below:

Male
\begin{tabular}{|c|c|c|c|c|c|}
\hline Tooth & $N$ & Mean & $\begin{array}{c}\text { Standard } \\
\text { deviation }\end{array}$ & Minimum & Maximum \\
\hline $1^{\text {st }}$ Premolar & 122 & -4.30 & 5.315 & -20 & +4 \\
\hline $2^{\text {nd }}$ Premolar & 126 & -0.15 & 3.306 & -10 & +4 \\
\hline $\begin{array}{c}1^{\text {st }} \text { molar } \\
\text { mesiobuccal }\end{array}$ & 125 & 1.87 & 2.413 & -7 & +7 \\
\hline $1^{\text {st }}$ molar distobuccal & 125 & 1.93 & 1.927 & -6 & +6 \\
\hline $1^{\text {st }}$ molar palatal & 125 & 1.85 & 2.547 & -8 & +7 \\
\hline $\begin{array}{c}2^{\text {nd }} \text { molar } \\
\text { mesiobuccal }\end{array}$ & 126 & 1.92 & 1.814 & -6 & +7 \\
\hline $2^{\text {nd }}$ molar distobuccal & 126 & 2.25 & 2.373 & -5 & +9 \\
\hline $2^{\text {nd }}$ molar palatal & 126 & 1.98 & 1.822 & -6 & +7 \\
\hline $3^{\text {rd }}$ molar & 108 & 1.21 & 2.327 & -5 & +6 \\
\hline
\end{tabular}

Female

\begin{tabular}{|c|c|c|c|c|c|}
\hline Tooth & $N$ & Mean & $\begin{array}{c}\text { Standard } \\
\text { deviation }\end{array}$ & Minimum & Maximum \\
\hline $1^{\text {st }}$ Premolar & 162 & -5.39 & 5.818 & -20 & +5 \\
\hline $2^{\text {nd }}$ Premolar & 171 & -0.85 & 4.322 & -20 & +3 \\
\hline $1^{\text {st }}$ molar mesiobuccal & 172 & 1.48 & 2.431 & -10 & +6 \\
\hline $1^{\text {st }}$ molar distobuccal & 172 & 1.44 & 2.274 & -9 & +7 \\
\hline
\end{tabular}

\begin{tabular}{|c|c|c|c|c|c|}
\hline $1^{\text {st }}$ molar palatal & 172 & 1.69 & 2.479 & -5 & +6 \\
\hline $\begin{array}{c}2^{\text {nd }} \text { molar } \\
\text { mesiobuccal }\end{array}$ & 174 & 1.92 & 2.067 & -7 & +6 \\
\hline $2^{\text {nd }}$ molar distobuccal & 174 & 2.05 & 2.199 & -7 & +7 \\
\hline $2^{\text {nd }}$ molar palatal & 174 & 1.78 & 2.265 & -9 & +7 \\
\hline $3^{\text {rd }}$ molar & 141 & 1.37 & 2.212 & -4 & +6 \\
\hline
\end{tabular}

The distance between the sinus floor and the root tip was longest for the first Premolar root tip, followed by the second Premolar root tip. The distance between the sinus floor and the root tip was shortest for the distobuccal root of the second molar, followed by the mesiobucal root tip of the second molar for both right and left sides. Statically no significant differences were found between the measurements for the right and left sides or between the male and female Patients $(\mathrm{P}>0.05)$

\begin{tabular}{|c|c|c|c|c|c|c|}
\hline \multirow{3}{*}{$1^{\text {st }}$ premolar } & \multicolumn{4}{|c|}{ Side } & \multicolumn{2}{|c|}{ Total } \\
\cline { 2 - 7 } & \multicolumn{2}{|c|}{ Right } & \multicolumn{2}{c|}{ Left } & \multicolumn{2}{c|}{} \\
\cline { 2 - 7 } & $\mathrm{N}$ & $\%$ & $\mathrm{~N}$ & $\%$ & $\mathrm{~N}$ & $\%$ \\
\hline Group 1 & 10 & 7 & 14 & 9.9 & 24 & 8.5 \\
\hline Group 2 & 17 & 12 & 18 & 12.7 & 35 & 12.3 \\
\hline Group 3 & 115 & 81 & 110 & 77.5 & 225 & 79.2 \\
\hline Total & 142 & 100 & 142 & 100 & 284 & 100 \\
\hline
\end{tabular}




\section{International Journal of Science and Research (IJSR)}

ISSN (Online): 2319-7064

Index Copernicus Value (2015): 78.96 | Impact Factor (2015): 6.391

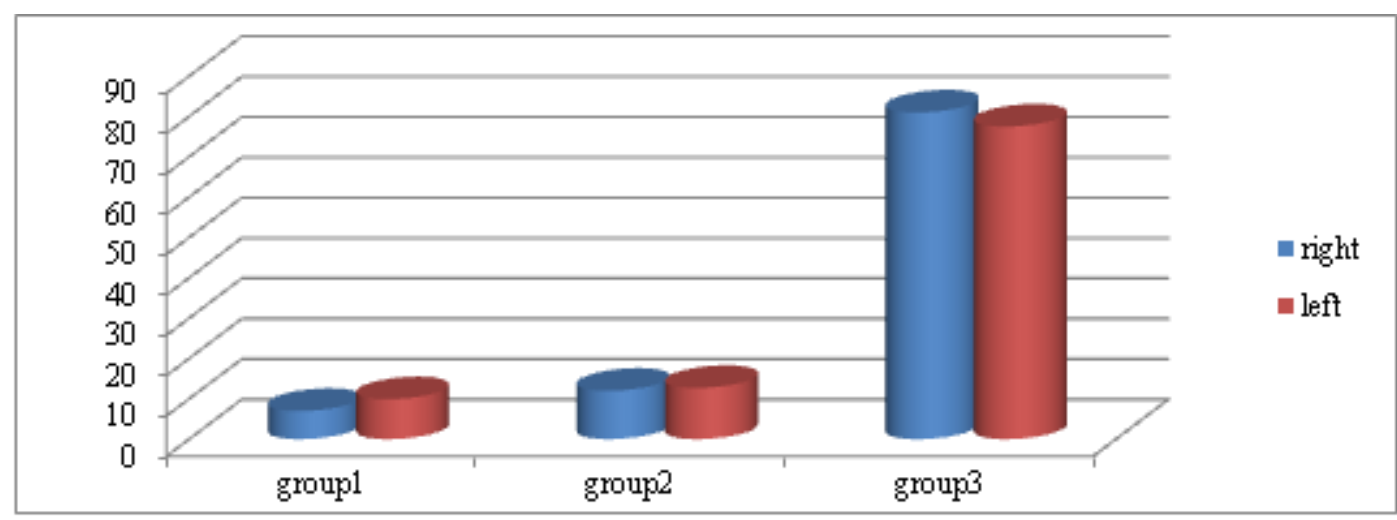

\begin{tabular}{|c|c|c|c|c|c|c|}
\hline \multirow{3}{*}{$\begin{array}{c}2^{\text {nd }} \\
\text { premolar }\end{array}$} & \multicolumn{4}{|c|}{ Side } & \multirow{2}{*}{\multicolumn{2}{|c|}{ Total }} \\
\hline & \multicolumn{2}{|c|}{ Right } & \multicolumn{2}{|c|}{ Left } & & \\
\hline & $\mathrm{N}$ & $\%$ & $\mathrm{~N}$ & $\%$ & $\mathrm{~N}$ & $\%$ \\
\hline Group 1 & 18 & 12.2 & 28 & 18.8 & 46 & 15.5 \\
\hline Group 2 & 70 & 47.3 & 64 & 43 & 134 & 45.1 \\
\hline Group 3 & 60 & 40.5 & 57 & 38.3 & 117 & 39.4 \\
\hline Total & 148 & 100 & 149 & 100 & 297 & 100 \\
\hline
\end{tabular}

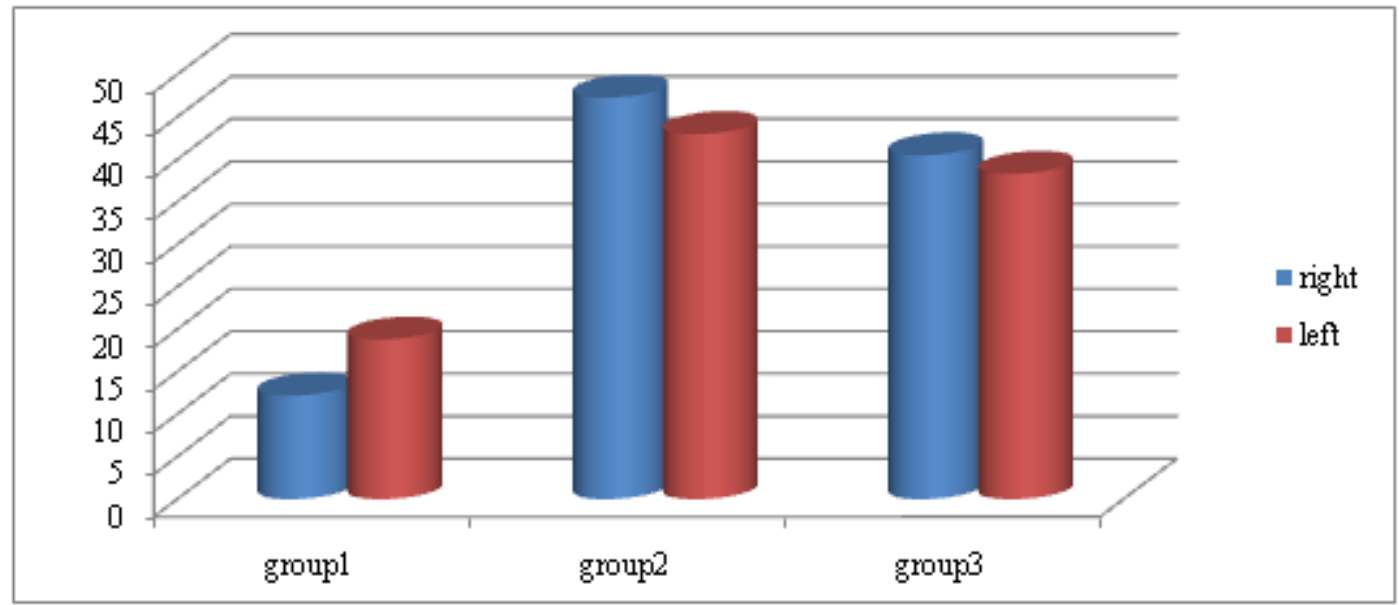

\begin{tabular}{|c|c|c|c|c|c|c|}
\hline \multirow{2}{*}{$\begin{array}{c}1^{\text {st }} \text { molar } \\
\text { mesiobuccal } \\
\text { root }\end{array}$} & \multicolumn{4}{|c|}{ Side } & \multicolumn{2}{|c|}{ Total } \\
\cline { 2 - 6 } & $\mathrm{N}$ & $\%$ & $\mathrm{~N}$ & $\%$ & $\mathrm{~N}$ & $\%$ \\
\hline Group 1 & 23 & 15.4 & 20 & 13.5 & 43 & 14.5 \\
\hline Group 2 & 103 & 69.1 & 105 & 70.9 & 208 & 70 \\
\hline Group 3 & 23 & 15.4 & 23 & 15.5 & 46 & 15.5 \\
\hline Total & 149 & 100 & 148 & 100 & 297 & 100 \\
\hline
\end{tabular}

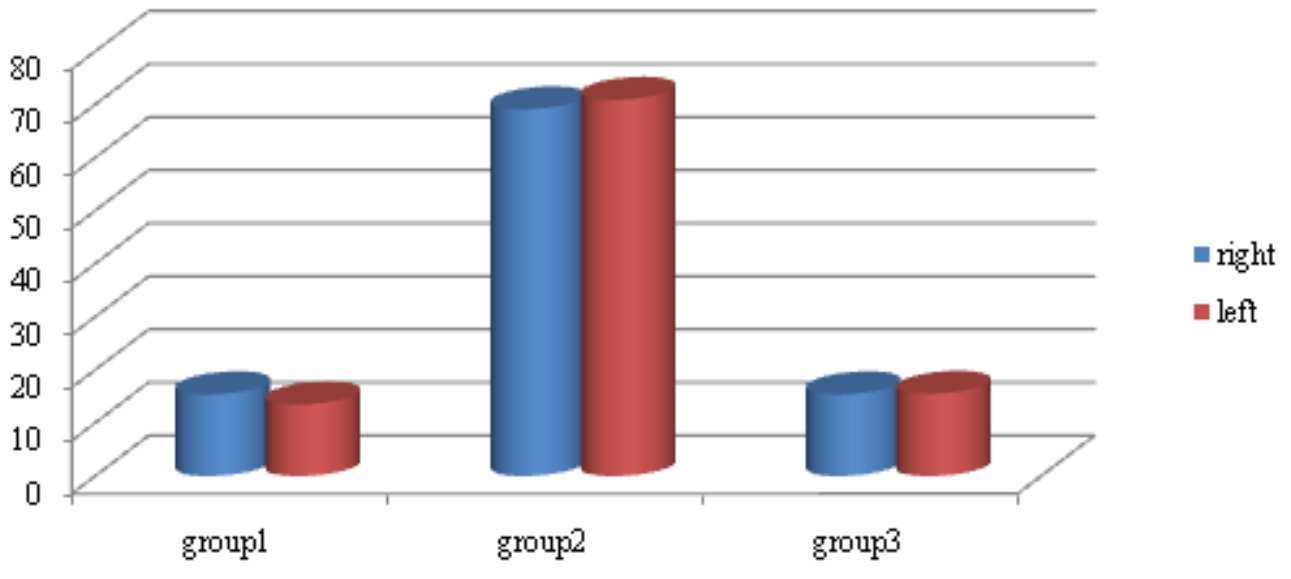

Volume 6 Issue 1, January 2017 www.ijsr.net

Licensed Under Creative Commons Attribution CC BY 
International Journal of Science and Research (IJSR)

ISSN (Online): 2319-7064

Index Copernicus Value (2015): 78.96 | Impact Factor (2015): 6.391

\begin{tabular}{|c|c|c|c|c|c|c|}
\hline \multirow{2}{*}{\begin{tabular}{c}
$1_{\text {st }}^{\text {distobuccal }} \begin{array}{c}\text { molar } \\
\text { root }\end{array}$ \\
\cline { 2 - 7 }
\end{tabular}} & \multicolumn{2}{|c|}{ Right } & \multicolumn{2}{c|}{ Total } \\
\hline Group 1 & $\mathrm{N}$ & $\%$ & $\mathrm{~N}$ & $\%$ & $\mathrm{~N}$ & $\%$ \\
\hline Group 2 & 108 & 16.8 & 13 & 8.8 & 38 & 12.8 \\
\hline Group 3 & 16 & 12.5 & 115 & 77.7 & 223 & 75.1 \\
\hline Total & 149 & 10.7 & 20 & 13.5 & 36 & 12.1 \\
\hline
\end{tabular}

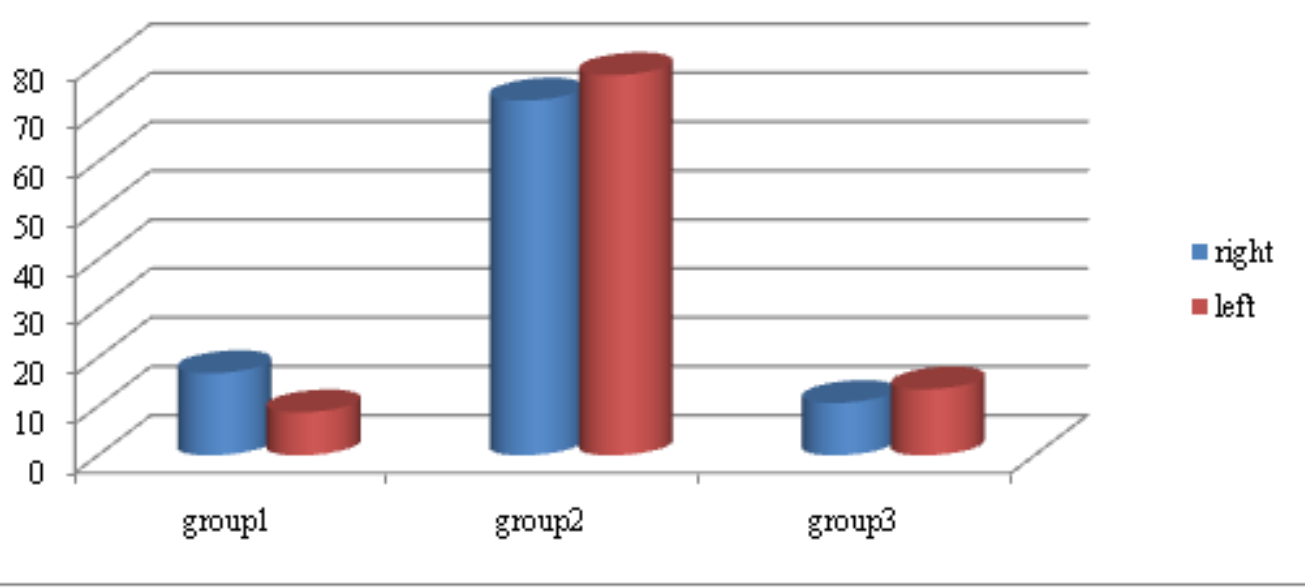

\begin{tabular}{|c|c|c|c|c|c|c|}
\hline \multirow{2}{*}{\begin{tabular}{c}
$1_{\text {st }}^{\text {molar }} \begin{array}{c}\text { palatal } \\
\text { root }\end{array}$ \\
\cline { 2 - 5 }
\end{tabular}} & \multicolumn{3}{|c|}{ Right } & \multicolumn{2}{|c|}{ Left } & \multicolumn{2}{c|}{ Total } \\
\hline Group 1 & $\mathrm{N}$ & $\%$ & $\mathrm{~N}$ & $\%$ & $\mathrm{~N}$ & $\%$ \\
\hline Group 2 & 18 & 12.1 & 17 & 11.5 & 35 & 11.8 \\
\hline Group 3 & 21 & 73.8 & 104 & 70.3 & 214 & 72.1 \\
\hline Total & 149 & 14.1 & 27 & 18.2 & 48 & 16.2 \\
\hline
\end{tabular}

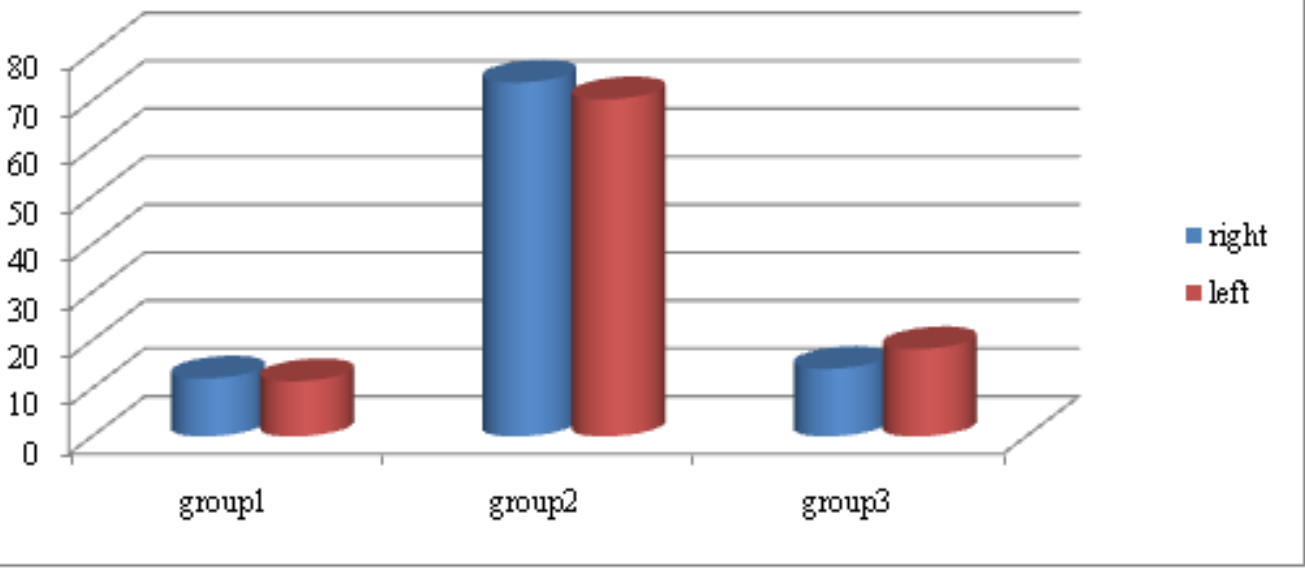

\begin{tabular}{|c|c|c|c|c|c|c|}
\hline \multirow{2}{*}{$\begin{array}{c}2^{\text {nd }} \text { molar } \\
\text { mesiobuccal } \\
\text { root }\end{array}$} & \multicolumn{4}{|c|}{ Side } & \multicolumn{2}{|c|}{ Total } \\
\cline { 2 - 5 } & \multicolumn{2}{|c|}{ Right } & \multicolumn{2}{c|}{ Left } & \multicolumn{2}{c|}{} \\
\hline Group 1 & 20 & 13.3 & 13 & 8.7 & 33 & 11 \\
\hline Group 2 & 113 & 75.3 & 125 & 83.3 & 238 & 79.3 \\
\hline Group 3 & 17 & 11.3 & 12 & 8 & 29 & 9.7 \\
\hline Total & 150 & 100 & 150 & 100 & 300 & 100 \\
\hline
\end{tabular}

Volume 6 Issue 1, January 2017

www.ijsr.net

Licensed Under Creative Commons Attribution CC BY 
International Journal of Science and Research (IJSR)

ISSN (Online): 2319-7064

Index Copernicus Value (2015): 78.96 | Impact Factor (2015): 6.391

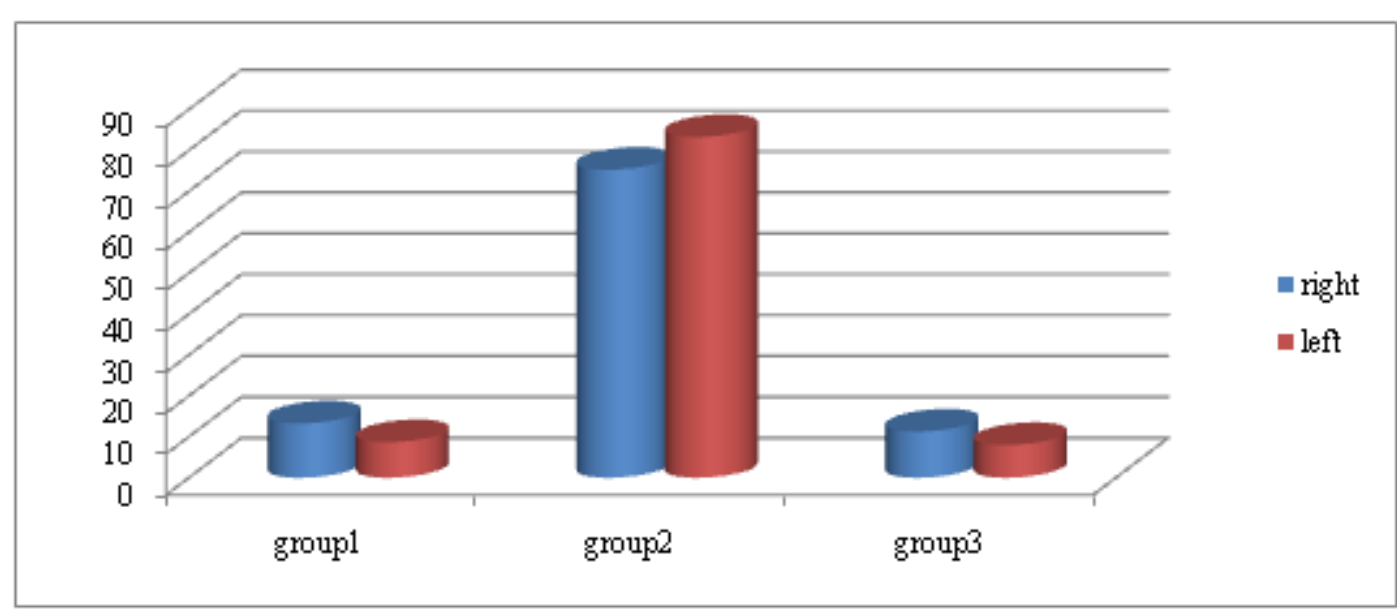

\begin{tabular}{|c|c|c|c|c|c|c|}
\hline \multirow{2}{*}{$\begin{array}{c}2^{\text {nd }} \text { molar } \\
\text { disto buccal }\end{array}$} & \multicolumn{4}{|c|}{ Side } & \multicolumn{3}{|c|}{ Total } \\
\cline { 2 - 5 } root & \multicolumn{2}{|c|}{ Right } & \multicolumn{2}{c|}{ Left } & \multicolumn{2}{c|}{} \\
\cline { 2 - 7 } & $\mathrm{N}$ & $\%$ & $\mathrm{~N}$ & $\%$ & $\mathrm{~N}$ & $\%$ \\
\hline Group 1 & 33 & 22 & 23 & 15.3 & 56 & 18.7 \\
\hline Group 2 & 104 & 69.3 & 113 & 75.3 & 217 & 72.3 \\
\hline Group 3 & 13 & 8.7 & 14 & 9.3 & 27 & 9 \\
\hline Total & 150 & 100 & 150 & 100 & 300 & 100 \\
\hline
\end{tabular}

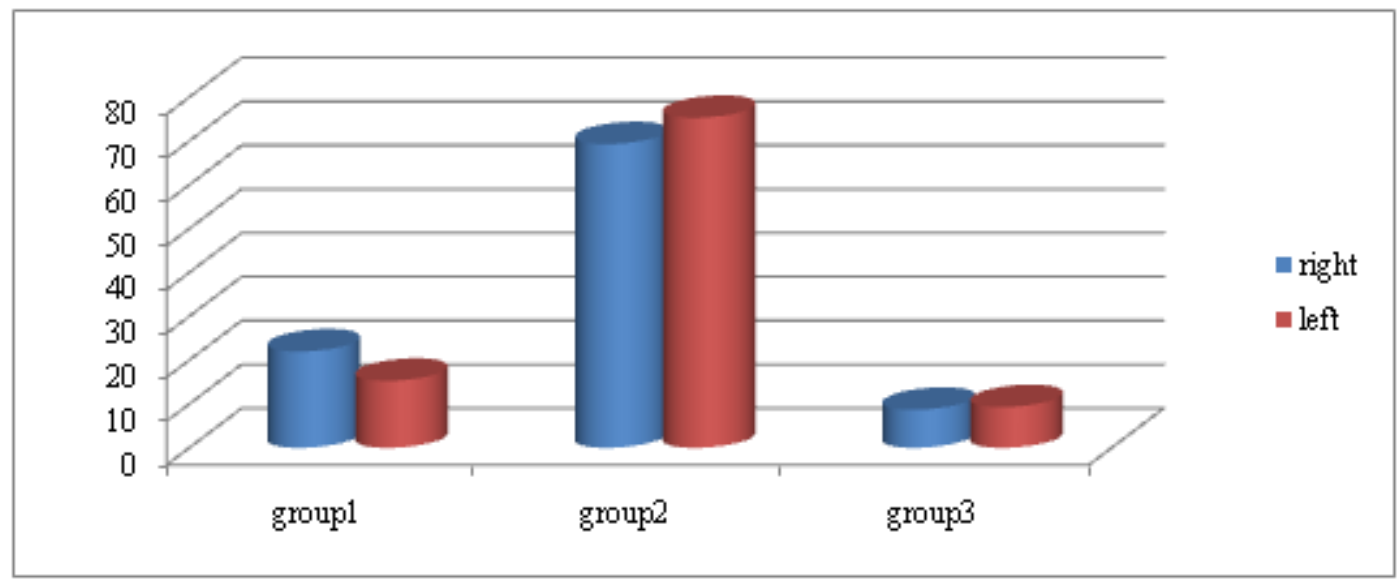

\begin{tabular}{|c|c|c|c|c|c|c|}
\hline \multirow{2}{*}{\begin{tabular}{c}
$2_{\text {nd }}^{\text {nd }} \begin{array}{c}\text { molar } \\
\text { palatal }\end{array}$ \\
\cline { 2 - 7 }
\end{tabular}} & \multicolumn{3}{|c|}{ Right } & \multicolumn{2}{c|}{ Total } \\
\cline { 2 - 7 } & $\mathrm{N}$ & $\%$ & $\mathrm{~N}$ & $\%$ & $\mathrm{~N}$ & $\%$ \\
\hline Group 1 & 12 & 8 & 17 & 11.3 & 29 & 9.7 \\
\hline Group 2 & 118 & 78.7 & 120 & 80 & 238 & 79.3 \\
\hline Group 3 & 20 & 13.3 & 13 & 8.7 & 33 & 11 \\
\hline Total & 150 & 100 & 150 & 100 & 300 & 100 \\
\hline
\end{tabular}

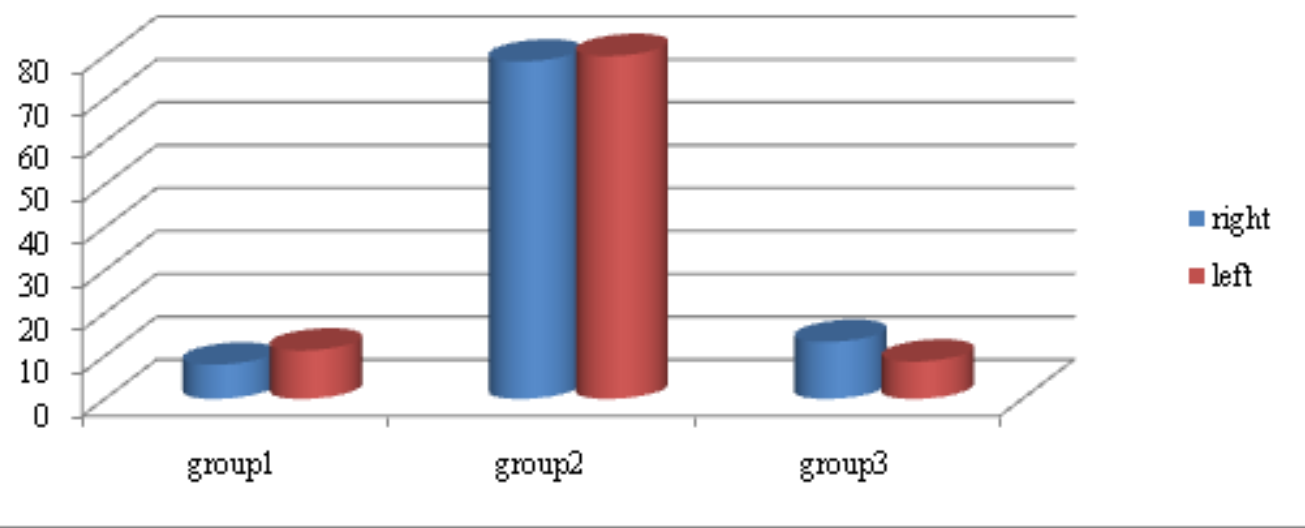

Volume 6 Issue 1, January 2017

www.ijsr.net

Licensed Under Creative Commons Attribution CC BY 
International Journal of Science and Research (IJSR)

ISSN (Online): 2319-7064

Index Copernicus Value (2015): 78.96 | Impact Factor (2015): 6.391

\begin{tabular}{|c|c|c|c|c|c|c|}
\hline \multirow{2}{*}{3} & \multicolumn{4}{|c|}{ Side } & \multicolumn{2}{|c|}{ Total } \\
\cline { 2 - 6 } molar & \multicolumn{2}{|c|}{ Right } & \multicolumn{2}{|c|}{ Left } & \multicolumn{1}{|c|}{} \\
\cline { 2 - 6 } & $\mathrm{N}$ & $\%$ & $\mathrm{~N}$ & $\%$ & $\mathrm{~N}$ & $\%$ \\
\hline Group 1 & 13 & 11 & 15 & 12 & 28 & 11.2 \\
\hline Group 2 & 84 & 69 & 82 & 64 & 166 & 66 \\
\hline Group 3 & 24 & 20 & 31 & 24 & 55 & 22.8 \\
\hline Total & 121 & 100 & 128 & 100 & 249 & 100 \\
\hline
\end{tabular}

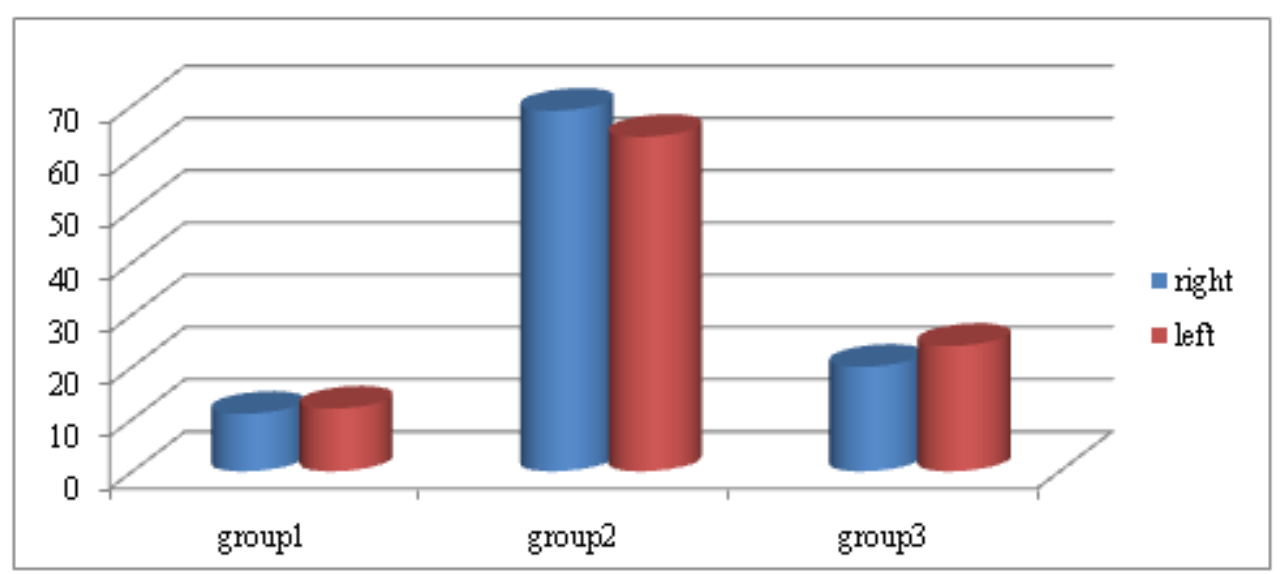

Totally for right side $22 \%$ of root tips were included in group 3,13\% in group 1 and $65 \%$ in group 2 . Where as on the left side $25 \%$ of root tip were included in group 3, 12\% in group 1 and $63 \%$ in group 2 .

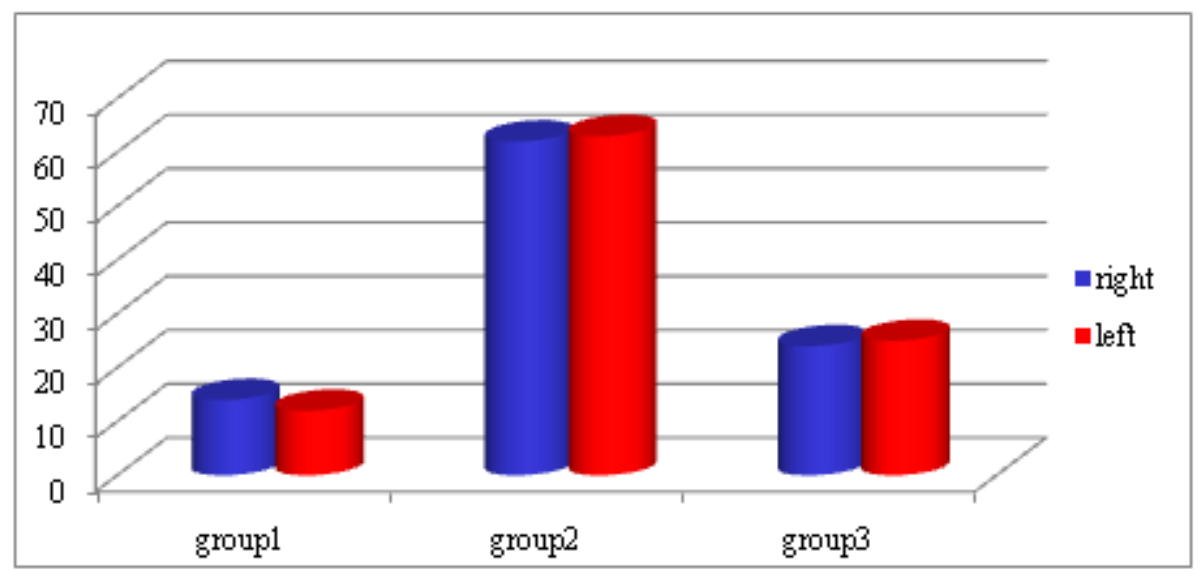

\section{Discussion}

Our study documents the anatomical the anatomical relationship between the root tips of maxillary posterior tooth and the maxillary sinus floor. Both right and left sides of each patient were evaluated separately.

The maxillary sinus is the largest of all the paranasal sinuses and, at 10 weeks in utero is the first to develop. After birth, sinus continues to pneumatize into the developing alveolar ridge as the permanent teeth erupt. At 12 to 13 years, the sinus floor is level with the nasal floor, and at age 20, with the completion of the eruption of the third molars, the pneumatization of the sinus ends, and the sinus reaches $5 \mathrm{~mm}$ inferior to the nasal floor. ${ }^{1}$ The inferior sinus wall is a curved structure formed by the lower third of the medial wall and the buccoalveolar wall, and the floor is formed by the alveolar process of the maxilla. The adult sinus is variable in its extension. In about half of the population, the sinus floor extends between adjacent teeth or individual roots, creating elevations in the antral surface, commonly referred to as 'hillocks'. The roots of the maxillary premolar, molar and occasionally canine teeth may project into the maxillary sinus. ${ }^{4}$

Because of the intimate relationship of the maxillary posterior tooth root apices to the maxillary sinus especially in the second molar and the first molar region, it has various implications in treatment planning in the dental field:

There is possibility for the root apices of the posterior tooth to be displaced into the sinus during procedures like extraction, further leading to complications like root apices being displaced into sinus leading to complications like oroantral communications and sinusitis. ${ }^{5}$ Hence the clinician must be careful in handling the apical portion of the roots in close proximity to the maxillary sinus floor.

Endodontic surgery of the premolars and molars can result in accidental oroantral communication that can allow bacteria from infected periapical tissues, resected root tips, or bone drilling dust to be displaced into the sinus causing acute or chronic sinusitis. Surgical treatment of posterior tooth is also complicated by redistricted space of the oral 


\section{International Journal of Science and Research (IJSR) \\ ISSN (Online): 2319-7064 \\ Index Copernicus Value (2015): 78.96 | Impact Factor (2015): 6.391}

vestibular region, which in turn makes it difficult to raise a flap. ${ }^{4}$

Sinus expansion after extraction can greatly decrease the bone height available for implant placement, ${ }^{22}$ hence clinicians conducting prosthetic and pre implant surgical procedures in the posterior maxilla must be aware of the degree of which teeth root protrude into the sinus because of the associated risk of the post extraction pneumatization, which reduces the amount of bone available at the implant or the denture or the denture site. ${ }^{2}$ So when ever a dental implant is planned in these cases, the clinicians should consider preserving as much bone height as possible by immediate implantation and or by immediate bone grafting at the time of extraction. These procedures might help maintain the three dimensional architecture of the thin sinus floor in the extraction site until complete healing of the socket takes place thus preventing or decreasing the pneumatization. ${ }^{1}$

Further more the distance between the root apices of the maxillary posterior teeth and the inferior wall of the maxillary sinus has a tendency to influence the orthodontic tooth movement, ${ }^{3}$ especially intrusion or bodily movement of the teeth across the sinus floor has been associated with a risk for root resorption and a higher degree of tipping. ${ }^{2}$ Orthodontic tooth movement through anatomical limitations such as sinus can be possible. Direction of tooth movement through sinuses could be achieved both postero-anteroir and vertical direction. Light and constant forces is necessary to accomplish these type of tooth movements. ${ }^{62}$ Hence the thickness of the inferior wall of the sinus and the relationship with the adjacent teeth is important for determining the prognosis of the orthodontic tooth movement

\section{Summary and Conclusion}

The results of our study indicate maxillary second and first molar to be in intimate relationship to the maxillary sinus with the distobuccal root of the maxillary second being closest to the maxillary sinus followed by the mesiobuccal root of the second molar. The maxillary first premolar is considered to be farthest away from the sinus followed by the maxillary second premolar.

Knowledge of the anatomical relationship between the maxillary sinus floor and the maxillary posterior teeth root tips is important for the preoperative treatment planning of maxillary posterior teeth. In view of the proximity of the maxillary sinus floor and maxillary root tips, clinicians must be cautious when performing dental procedures involving the maxillary posterior teeth particularly the first and second molars. The measurements found in the present study highlight the need for preoperative treatment planning.

\section{References}

[1] ArbelSharan, David Madjar. Maxillary sinus pneumatization following extraction: a radiographic study. Intjou oral maxillofacial implants

[2] ArbelSharan, David Madjar, Tel Hashomer. Correlation between maxillary sinus floor topography and related root position of the posterior teeth using panoramic andcrossectional computed tomography imaging. Oral surgery oral medicine oral pathology oral radilolgy and endodontology vol.102 no.3 sep 2006.

[3] H. H. Kwak, H. D. Park, H. R. Yoon, M. K. Kang, K. S. Koh, H. J. Kim: Topographic anatomy of the inferior wall of the maxillary sinus in Koreans. Int. J. Oral Maxillofac. Surg. 2004; 33: 382-388

[4] Kilic, C., Kamburoglu, K., Yuksel, S.P. and Ozen, T. (2010) An assessment of the relationship between the maxillary sinus floor and the maxillary posterior teeth root tips using dental cone-beam computerized tomogra-phy. European Journal of Dentistry, 4, 462-467

[5] Harrison DF. Oro-antral fistula. Br J ClinPract. 1961 Feb;15:169-74.

[6] Waite, D.E. (1971) Maxillary sinus. Dental Clinics of North America, 15, 349-368

[7] Harrison DFN. Surgical anatomy of maxillary and ethmoidal sinuses - a reappraisal.Laryngoscope 1971: 81: 1658-1664.

[8] Sicher H, Lloyd-Dubrul E. Oral Anatomy. 6th edn. St. Louis: Mosby Co. 1975:315.

[9] Williams PL, Warwick-R (eds): Gray's Anatomy (ed 36). Philadelphia, PA, Saunders, 1980, -340. 1149

[10] Falk, Ericson \&Hugoson the effects of periodontal treatment on mucous membrane thickening on the mucous membrane. Jouclin periodontal 13:217, 1986

[11] Cohen S, Burns R. pathways of the pulp. St Louis:cvmosby 1987:18

[12] Yoon H. R., Park C. S.,A radiologic study of the relationship of the maxillary sinus floor and apex of the maxillary molar, J Korean Acad Oral Maxillofac Radiol,1998, 28(1):111-126

[13] Helene Engstrom, Durwin Chamberlain, Robert Kiger and Jan Egelberg, radiographic evaluation of the effect of intial periodontal theraphy on thickness of the maxillary sinus mucosa. Jou periodontal September, 1988 vol 59 no 9

[14] OrhanGiiven A clinical study on oroantral fistulae JowT al of Cranio- Maxil\#)facia[ Surgery (1998) 26, 267-271

[15]LANG J. The maxillary sinus and teeth.Clinical Anatomy of the Nose, Nasal Cavity and Paranasal Sinuses. New York: Thieme Medical Publishers, Inc. 1989: 76-79.

[16] Wehrbein H, Bauer W, Wessing G, Diedrich P. The effect of the maxillary sinus floor on orthodontic tooth movement.FortschrKeiferorthop 1990; 51:345-51.

[17] Friedman S, Lustmann J, Shaharabany V. Treatment results of apical surgery in premolar and molar teeth. $\mathrm{J}$ Endod 1991;17:30-33.

[18] Eberhardt, J.A., Torabinejad, M. and Christiansen, E.L. (1992) A computed tomographic study of the distances between the maxillary sinus floor and the apices of the maxillary posterior teeth. Oral Surgery, Oral Medicine, Oral Pathology, 73, 345-346.

[19] Wehrbein H, Diedrich P. Progressive pneumatization of the basal maxillary sinus after extraction and space closure]. FortschrKieferorthop. 1992 Apr;53(2):77-83.

[20] James AEberhardt, Mahmoud Torabinejad and Edwin I. Christiansen. A computer tomographic study of the distance between the maxillary sinus floor and the apices of the maxillary posterior teeth, oralsur oral med oral pathol 1992;73:345-6 


\section{International Journal of Science and Research (IJSR) \\ ISSN (Online): 2319-7064}

Index Copernicus Value (2015): 78.96 | Impact Factor (2015): 6.391

[21] Mustian WF. The floor of the maxillary sinus and its dental and nasal relation. J Am Dent Assoc 1933: 20: 2175-2187.

[22] Misch CE. Contemporary oral and maxillofacial surgery, ed 2.st Louis:mosby, 1993:465

[23] Freisfeld, M., Drescher, D., Schellmann, B. and Schüller, H. (1993)The maxillary sixth-year molar and its relation to the maxillary sinus. A comparative study between the panoramic tomogram and the computed tomogram. Fortschritte der Kieferorthopädie, 54, 179186

[24] Mustian WF. The floor of the maxillary sinus and its dental and nasal relation. J Am Dent Assoc 1933: 20: 2175-2187.

[25] McGrowan DA, Baxter PW, James J. The Maxillary Sinus and its Dental Implications. 1st ed. London: Wright Co.,1993:1-25.

[26] Ariji, Y., Kuroki, T., Moriguchi, S., Ariji, E. and Kanda, S. (1994) Age changes in the volume of the human max-illary sinus: A study using computed tomography. DentoMaxillo Facial Radiology, 23, 163168.

[27] 10-Reddy MS, Mayfield-Donahoo T, Vanderven FJ, Jeffcoat MK. A comparison of the diagnostic advantages of panoramic radiography and computed tomography scanning for placement of root form dental implants. Clin. Oral Implants Res 1994;5: 229-38.

[28] Norman J. Betts, DDS, MS, and Michael Miloro, DMD, MDTModification of the Sinus Lift Procedure for Septa in the Maxillary AntrumJ Oral MaxillofacSurg 52332-333.1994

[29] Wehrbein H, Fuhrmann RAW, Diedrich PR. Human histologic tissue response after long-term orthodontic tooth movement. Am J OrthodDentofacialOrthop 1995; 107:360-71

[30] Williams PL, Bannister LH, Berry MM et al. Gray's anatomy. 38th ed. New York: Churchill-Livingstone, 1995:1239

[31] James A, Wallance, MS Pittsburgh.Transantral endodontic surgery. Oral surgery oral medicine and oral pathology vol 82 no1 july 1996.

[32] Nicolaas M. Timmenga, MD, DDS," Gerry M. Raghoebar, MD, DDS, PHD, T Geert Boering, DDS, PHD, and Ranny Van Weissenbruch, Maxillary Sinus Function After Sinus Lifts for the Insertion of Dental Implants J Oral MaxillofacSurg 55:936-939, 1997

[33] Fontenelle A. Challenging the boundaries of orthodontic tooth movement. In: Sachdeva RCL, editor. Orthodontics for the next Millennium. Orange CA: Ormco, 1997:246-67

[34] Watzek G, Bernhart T, Ulm C. Complications of sinus perforations and their management in endodontics. Dent Clin North Am 1997;41:563-583

[35] Fuhrmann R, Bucker A, Diedrich. Radiological assessment of artificial bone defects in the floor of the maxillary sinus. DentomaxillofacRadiol 1997: 26: 112116

[36] Yuki Uchida, Masaaki Goto, Takeshi Katsuki, Yoshikazu Soejima,Measurement of Maxillary Sinus Volume UsingComputerized Tomographic Images (INT J ORAL MAXILLOFAC IMPLANTS 1998;13:811818)
[37] Abubaker, A.O. (1999) Applied anatomy of the maxillary sinus. Oral and Maxillofacial Surgery Clinics of North America, 11, 1-13.

[38] Paul A, Fugazzotto. Sinus floor augmentation at the time of maxillary molar extraction: technique and report of preliminary results. Intjou oral maxillofac implants 1999; 14:536- 542

[39] Wiltfang J., Schultze-Mosgau S., Merten H. A., Kessler P., Ludwig A., Engelke W.,Endoscopic andultrasonographic evaluation of the maxillary sinus aftercombined sinus floor augmentation and implant insertion, Oral Surg Oral Med Oral Pathol Oral RadiolEndod, 2000, 89(3):288-291

[40] Tyndall, Brook, Chapel Hill and Ann Arbor.Selectinal criteria for dental implant site imaging: a position paper of the American academy of oral and maxillofacial radiology .oral surgery oral medicine and oral pathology vol89, no 5 may 2000.

[41] Hauman CH, Chandler NP, Tong DC. Endodontic implications of the maxillary sinus: a review. IntEndod J. 2002 Feb;35(2):127-41

[42] Paul A Fugazzoto, immediate implant placement following a modified trephine/osteotme approach: success rates of 116 implants to 4 years in function. Intjou of oral \& max fac implants.

[43] Takahisa N.,Morphometry of the maxillary sinus with the use of CT images: change with aging and relationship between sinus floor and tooth roots, Nihon Univ J Oral Sci,2002, 28(1):7-18

[44] Daimaruya T, Takahashi I, Nagasaka H, Umemori M, Sugawara J, Mitani H. Effect of maxillary molar intrusion on the nasal floor and tooth root using the skeletal anchorage system in dogs. Angle Orthod 2003; 73:158-6.

[45] Yao CCJ, Wu CB, Wu HY, Kok SH, Chang HF, Chen YJ. Intrusion of the overerupted upper left first and second molars by mini-implants with partial-fixed orthodontic appliance: a case report. Angle Orthod 2004

[46] Bouquet A, Coudert JL, Bourgeois D, Mazoyer JF, Bossard D. Contributions of reformatted computed tomography and panoramic radiography in the localization of third molars relative to the maxillary sinus. Oral Surg Oral Med Oral Pathol Oral RadiolEndod. 2004 Sep;98(3):342-7.

[47] Wehrbein H, Bauer W, Wessing G, Diedrich P. Der einflub des kieferhohlenbodens auf die orhodontischezahndewegung.

Fortschrittekieferothopadie 1990: 51: 345-351

[48] White SC, Pharoah MJ. Intraoral radiography. In: White SC, Pharoah MJ, editors. Oral radiology: principles and interpretation. 5th ed. St. Louis: Mosby: 2004; p. 77-90.

[49] Koppe T., Nakatsukasa M., Yamanaka A.,Implication of craniofacial morphology for the pneumatization pattern of the human alveolar process, ActaMedicaLituanica, 2005,12(1):40-46.

[50] Tank PW. Grant's Dissector. 13 ed. Philadelphia: Lippincott Williams \& Wilkins, 2005:198.

[51] Sharan A, Madjar D. Correlation between maxillary sinus floor topography and related root position of posterior teeth using panoramic and cross-sectional computed tomography imaging. Oral Surg Oral Med 


\section{International Journal of Science and Research (IJSR) \\ ISSN (Online): 2319-7064}

Index Copernicus Value (2015): 78.96 | Impact Factor (2015): 6.391

Oral Pathol Oral RadiolEndod. 2006 Sep;102(3):37581. Epub 2006 Jun 8.

[52] Ole T. Jensen, DDS, MS, Carl Brownd, DDS, MS, and David Baer, BSMaxillary Molar Sinus Floor Intrusion atthe Time of Dental Extraction American Association of Oral and Maxillofacial Surgeons J Oral MaxillofacSurg 64:1415-1419, 2006.

[53] Koch, F., Breil, P., Marroquín, B.B., Gawehn, J. and Kunkel, M. (2006) Abscess of the orbit arising $48 \mathrm{~h}$ after root canal treatment of a maxillary first molar. Interna-tional Endodontic Journal, 39, 657-664.

[54] Arbel S, Correlation between maxillary sinus floor topography and related root position of posterior teeth using panoramic and cross-sectional computed tomography imaging 2006

[55] V. Nimigean1), Vanda Roxana Nimigean2), Nicoleta $\mathbf{M} \square$ ru1),D. I. $\mathbf{S} \square \mathbf{I} \square \mathbf{v} \square$ stru1), Daniela $\mathbf{B} \square \operatorname{di} \square \square$ 3), Mihaela Jana $\square$ uculin $\square$ 4, The maxillary sinus floor in theoral implantology, Romanian Journal of Morphology and Embryology 2008, 49(4):485-489

[56] Kenneth M.T. Low, BDS, , Karl Dula, PD DMD, Walter Bürgin, MS, BE, and Thomas von Arx, PD DMD Comparison of Periapical Radiography and Limited Cone-Beam Tomography in Posterior Maxillary Teeth Referred for Apical Surgery (J Endod 2008;34:557-562

[57] Maestre-Ferrín L, Galán-Gil S, Rubio-Serrano M, Peñarrocha-Diago M. Maxillary sinus septa: a systematic review. Med Oral Patol Oral Cir Bucal. 2009 Sep 21

[58] Maryam Shahbazian1, Dong Xue2, Yuqian Hu2, Johan van Cleynenbreugel, ReinhildeJacobs1 Spiral Computed Tomography Based Maxillary Sinus Imaging in Relation to Tooth Loss, Implant Placement and Potential Grafting ProcedureJ Oral Maxillofac Res 2010 (Jan-Mar) | vol. 1 | No 1 | e7 | p.1

[59] 1-Baratto F, Zaitter S, Haragushiku G, De Campos E, Abuabara A, Correr GM. Analysis of the internal anatomy of maxillary first molars by using different methods. J Endod. 2009; 35:337-42.

[60] 2-Neelakantan P, Subbarao C, Ahuja R, Subbarao CV, Gutmann JL. Cone-beam computed tomography study of root and canal morphology of maxillary first and second molars in an Indian population. J Endod. 2010 Tomography. (Eur J Dent 2010;4:462-467

[61] Bassam A. Hassan Reliability of Periapical Radiographs and Orthopantomogramsin Detection of Tooth Root Protrusion in the Maxillary Sinus:Correlation Results with Cone Beam Computed Tomography J Oral Maxillofac Res 2010 (Jan-Mar) vol. 1 | No 1 | e6 | p.2

[62] SujidtraChaiyasang,SupraneeDeesamerOrthodontic tooth movement through maxillary sinus Srinagarind Med J 2010; 25(2): 156-61.

[63] Shakhawan M. Ali BDS, HDD.(1) Falah A. Hawramy BDS, HDD, FICMS (2) Kawa A.MahmoodMBChB, FICMS The Relation of Maxillary Posterior Teeth Roots to the Maxillary Sinus Floor Using Panoramic and Computed Tomography Imaging in a Sample of Kurdish People Tikrit Journal for Dental Sciences 1(2012)81-88

[64] Yun-Hoa Jung, Bong-Hae ChoAssessment of the relationship between the maxillary molars and adjacent structures using cone beam computed tomography Imaging Science in Dentistry 2012; $42: 219-24$

[65] Georgescu CE, Rusu MC, Sandulescu M, Enache AM, Didilescu AC. Quantitative and qualitative bone analysis in the maxillary lateral region. SurgRadiolAnat 2012; 34 : 551-8.

[66] PhothikhunS,SuphanantachatS,ChuenchompoonutV ,Nisapakultorn K. Cone-beam computed tomographic evidence of the association between periodontal bone loss and mucosal thickening of the maxillary sinus. J Periodontol 2012; 83 : 557-64.

[67] Andreea Didilescu1,2, Mugurel Rusu3, Mihai Săndulescu4, Carmen Georgescu5, Radu Ciuluvică6 Morphometric analysis of the relationships between the maxillary first molar and maxillary sinus floor. Open Journal of Stomatology, 2012, 2, 352-357. 